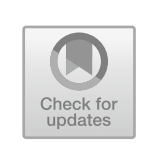

\title{
Conventional and Critical Approaches \\ to Peace Education
}

\begin{abstract}
Peace and education are both "essentially contested concepts." Welding them together in one single term-peace education-raises tough questions about what it is that is being proposed and done. With their normative, morally appellative and culturally universalist focus on the individual learner, conventional conceptions and practices of peace education do not easily relate to variable, heterogeneous and contextdependent notions and realities of peace and education in violenceinflected societies. They also shy away from taking account of asymmetric and unequal power relationships. Evoking the importance of building "cultures of peace" falls short of addressing these realities. Critical approaches to peace education forefront empowering individuals as well as collectives to become agents of social transformation. Education for peace is understood as social action geared towards finding solutions to manifold manifestations of direct, cultural and structural violence, injustice and inequality. Critical peace education is more attuned to the thorny issues of power and exclusion. However, it faces the challenge of showing how the empowerment and emancipation of the marginalised and oppressed through formal and informal education for peace can lead to broader institutional transformation. The chapter illustrates peace education's challenges in relation to the case of Colombia.
\end{abstract}

Keywords Peace education · Cátedra de la Paz (Peace Chair) - Violent conflict · Colombia 
Since the early days of peace research in the 1960s, it has often been noted that what is labelled peace education or education on and/or for peace is a field of scholarly enquiry and educational praxis that cannot be easily classified and delimited (see, for instance, Banks 1974; Cremin 2016; Galtung 1974; Jaeger 2014; Lum 2013; Mushakoji 1974; Nicklas and Ostermann 1974; Salomon 2002; Wiberg 1974). ${ }^{1}$ However could it, one must ask, given that both peace and education are terms that defy straightforward definition? Peace-as a notion, reality, ideal and utopia - carries a plurality of meanings, promises and hopes across time and space. ${ }^{2}$ To some, it may mean the absence of varying forms of direct, structural and cultural violence, as in Johan Galtung's negative conception of the term (Galtung 1969, 2012, 2017). ${ }^{3}$ For those more inclined towards the Norwegian peace scholar's positive conceptualisation, it may refer to "an optimal environment in which human potential can flourish" (Institute for Economics \& Peace 2019: 67), where "hatred, antipathy and indifference" between individuals and collectives, such as communities, states and nations, are replaced by "sympathy" and "cooperation" (Galtung 2012: 53). More emphatically even, peace is seen

${ }^{1}$ It is worthwhile to recall here the observation of Johan Galtung, the seminal Norwegian peace and peace education scholar-practitioner, that in its beginnings peace research had a challenging time becoming established at universities in Europe and North America. When the emerging academic discipline finally moved from the margins and from what today would be called thinktanks into the higher education sector, it was strong on research but weak on education (Galtung 1974). While many efforts have since been made to integrate research and education on peace, and a plethora of study and learning programmes have been set up at universities and specialised training institutes, including in countries of the South, research and education on peace and violent conflict still do not communicate as much as they should with one another (Senghaas, cited in Frieters-Reermann 2009).

2 In illustration, based on a search of the Thomson Reuters Web of Knowledge database on "articles published in English since 2000 with 'peace' in their title," Peter Coleman found more than "40 terms distinguishing different types or aspects of peace. [...] Peace can differ in a variety of ways, including by level (interpersonal to international to global peace), direction (internal and external peace), durability (from fragile to enduring peace), source or conditions (peace through coercion, democratic participation, economic incentive, etc.), type (negative, positive and promotive peace) and scope (local to global peace)" (Coleman 2013: 103).

3 According to Galtung, direct violence involves acts geared towards inflicting physical harm and destruction on others, while structural and cultural violence manifest in the exploitation of others and patterns of justification of both direct and structural violence, respectively (Galtung 2012). 
as a "moral aspiration, social good, universal value and a human right (author's translation)" (Arias 2016: 244). It is "a linchpin of social harmony, economic equity and political justice," which, however, is always at peril of being "ruptured by wars and other forms of violent conflict" (Webel 2007: 5-6). Dialectic in nature, peace "as social formation has forces and counter-forces" prompting cyclical movement from peace to peacelessness and back again. In this movement, returning to the point of peaceful equilibrium requires, however, that these cycles are "handled non-violently-constructively-creatively" (Galtung 2012: 12). Others still, operating at the fringes of the realist paradigm in International Relations, would like to make us believe-misleadingly, to my mind-that peace is nothing but the seedbed of, and a somehow artificial interval between, never-ending violent conflict and war (Walt 2016).

Not as contentious as peace, education-conventionally defined as the "process of teaching, training and learning, especially in schools, colleges or universities, to improve knowledge and develop skills" (Hornby 2000: 401 ) - too is not free of ambiguity and controversy. Recall, for instance, the powerful post-colonial critiques put forward by pedagogues like Paulo Freire in the 1960s, who saw modern education as either an elitist instrument designed to integrate (some of) the young into the extant social and economic systems and achieve conformity or to strengthen, in much broader and inclusionary fashion, the upcoming generations' ability to seek freedom and develop their potential to transform the world (Freire 1968; Harber 2004). Several decades later, in the early twenty-first century, education appears to be on the way to becoming more standardised as well as more widely accessible across countries and cultures. But "education is $[\ldots]$ in crisis," writes Hilary Cremin, "because it has failed to bridge the growing gap between the rich and the poor. [...] Processes of marketisation have resulted in education being reduced to a commodity to be consumed like any other" (Cremin 2016: 5). Significant variations in approach and levels of access to, and provision of, education remain. Pedagogical practice and quality, from primary through to tertiary and vocational education and adult learning, and the very definition of the ultimate ends of education vary, sometimes greatly, within and between countries - and not only between those in the global North and South (Cremin 2016; Tierney 2011). "In many ways," observes Liz Jackson, "global convergence around educational policies, practices, and values can be observed. [...] Yet educational borrowing and transferral 
remain unstraightforward in practice, as educational and cultural differences across social contexts remain, while the ultimate ends of education [...] are essentially contested" (Jackson 2020: 17).

Hence, welding together the concepts of peace and education in one single term-peace education - is bound to raise questions, as was already noted by Håkan Wiberg close to half a century ago (Wiberg 1974), about what it is that is being proposed and done; and how it is done and by whom and for what purpose. As a political scientist with a practical interest in peace education in countries affected by violent conflict, I am under the impression that the field continues, after decades of scholarly and applied efforts, to wrestle with defining more clearly its identity as an academic and educational discipline and ground lofty aspirations more firmly in evidence and theory. This is echoed, for instance, by outspoken authors like Ilan Gur-Ze'ev, who chastises peace education researchers and practitioners for not engaging sufficiently with "the reciprocity of its two fundamental concepts, $[\ldots]$ peace and $[\ldots]$ education; $[\ldots]$ and the relation between power and violence [as well as] the fruitful tension between peace and freedom" (Gur-Ze'ev 2010: 172). Others, such as Norbert Frieters-Reermann and Uli Jaeger, highlight peace education's inherent value and desirability but are clear that the field—still— lacks a solid theoretical base which cannot be built without generating more hard evidence about its effectiveness and impact (Frieters-Reermann 2009, 2010; Jaeger 2006, 2014). For the time being, "peace education [therefore] remains [...] indispensable but controversial, value-oriented but without a claim to truth (author's translation)" (Jaeger 2006: 16).

\subsection{Conventional Approaches to Peace Education}

The hallmark of conventional peace education scholarship and practice, which is characterised by a normative outlook, is its focus on shaping individual attitudes, beliefs, behaviours and values with the aim of shaping "hearts and minds" in support of peace (Salomon 2010). According to one seminal exponent of this school, "peace studies tend to focus on the causes of war, and alternatives to war, whereas peace education is more generic, attempting to draw out of people their natural inclinations to live in peace. [...] Peace educators $[\ldots]$ are interested in all distinct aspects of violence from the interpersonal to the geopolitical. They see that education provides an important strategy to achieve peace, because it provides awareness about different peace strategies (emphasis added)" 
(Harris 2002: 18). Focussed on changing attitudes in individuals, that is, students, but ultimately aiming at bringing about behavioural change, Ian Harris posits that peace education works on five levels: it "(1) [...] explains the roots of violence; (2) [...] teaches alternatives to violence; (3) [...] cover[s] different forms of violence; (4) [understands] peace itself [as] a process that varies according to context; and (5) [recognises that] conflict is omnipresent" (Harris 2004: 6).

Harris' $(2002,2004)$ approach, as well as that of others writing in a similar vein (Bar-Tal 2002; Harris and Morrison 2013; Howlett and Harris 2010), rests on the premise that peace education "represents an indirect solution to the problems of violence. As a strategy it depends upon millions of students being educated, who first transformed their inner hearts and minds and then must turn work to transform violence" (Harris and Morrison 2013: 31). However, acknowledging that we do not know with certainty "how and why [and whether] peace education programmes work" (Harris and Morrison 2013: 31), ${ }^{4}$ this scholarship concedes that "the struggle to achieve peace takes place at both the individual and social levels" (Harris 2004: 16). Thus "peace education theory has to account for efforts to achieve peace at both the micro and macro levels" (Harris 2004: 16).

Yet it is precisely this question about how to link the level of the individual, on the one hand, and the social and/or political-institutional or macro-levels on the other that in conventional approaches remains unresolved (Ross 2010). Some scholars have attempted to address the issue by taking recourse to socialisation and reconciliation theory (Bar-Tal 2002; Bar-Tal et al. 2010; Boulding 1974, 2002; Harris and Morrison 2013; Zwick 2006). These approaches are based on the premises that the "emergence and development of the human personality is dependent upon [...] the social and material living conditions that exist at a certain point in time in the historical development of a society (author's translation)" (Hurrelmann, cited in Zwick 2006: 13); and that "reconciliation supports and solidifies peace as a new form of intergroup relations and serves

4 The difficulty of establishing the effects and impact of peace education on students' attitudes, behaviours, beliefs and values is a recurrent topic in the literature. If at all, thus far authors have offered mostly anecdotal evidence about such effects, while it is recognised that there is a need for more systematic and methodologically more sophisticated evaluations of peace education (Bar-Tal 2002; Danesh 2008; Frieters-Reermann 2010; Harris and Lewer 2005; Ross 2010). 
as a stable foundation for cooperative and friendly acts that symbolise these relations" (Bar-Tal et al. 2010). Even when the mentioned conception of socialisation has been critiqued for suggesting too plainly that the social and material environment in which humans-especially children and youngsters-live and develop agency is constituted in such a clear-cut manner that individuals can and will adopt established (traditional) cultural norms and values rather unambiguously, it is nonetheless held that peace pedagogy can contribute to "socialising" learners into becoming peaceful, non-violent members of society (Zwick 2006; see also Boulding 1974).

Put simply, pro-peace attitudes, beliefs, behaviours and values can be proactively fomented in individuals if and when they are supported by, and reflected in, their broader social and material environment. ${ }^{5}$ Vice versa, positive socialisation effects achieved through peace education are believed to strengthen and enhance the sustainability of a peaceful environment. Likewise, peace education is styled as "one of the most prominent and efficient methods for promoting reconciliation" because it helps to "construct students' worldview [...] in a way that facilitates conflict resolution and [...] that prepares them to live in an era of peace [...]" (Bar-Tal et al. 2010). However, while one can imagine such positive feedback and reconciliation processes occurring in more stable environments where levels of violent conflict, polarisation and social exclusion and inequality are low, we cannot be sure that this also applies to communities and countries affected by elevated levels of political and other forms of violence. Researchers who are more attuned to the challenges peace education faces in violent contexts and settings characterised by deep ethnic and other cleavages suggest that there is no convincing evidence that would support any such claims.

In this respect, Gavriel Salomon $(2002,2010)$ is to be credited with contributing a basic three-tier typology of peace education contexts in which he distinguishes between contexts of (a) relative tranquillity, (b) latent ethno-political tensions and (c) intractable and belligerent conflicts.

5 In an early contribution to this debate, Elise Boulding suggested that the "life experience of persons committed to a belief in, and action on behalf of, non-violent social change" must include such high-aiming features as "optimal opportunities as a child for development of emotional, cognitive and intuitive capacities in home, school and community [...]"; "substantial exposure to a variety of adult and peer role models in different kinds of social settings" and "experiences of rewarding social feedback in the playing out of roles and solving problems" (Boulding 1974: 103-104). 
While peace education is frequently practised at schools and other educational establishments in countries that may be considered to be settings of "relative tranquillity," such as in Europe and North America, it is in settings with intractable armed conflicts that "peace education faces its real test for here it is about making peace with the real enemy. [...] The proposed contextualisation sharpens awareness of the need for peace education programmes to be precisely aligned to the specific conflict setting" (Jaeger 2014: 4). According to Uli Jaeger, peace education in violent conflict settings "aims to initiate and support integrated, holistic learning processes $[\ldots]$. In these learning processes, the main goal is $[\ldots]$ to promote constructive ways of dealing with the potential for conflict and violence and thus help build the peace skills of individuals and groups alike" (Jaeger 2014: 5).

Recognising the centrality of the broader social and cultural context in which peace education takes place, the cultures of peace movement, which since the 1990s has been promoted by the United Nations Educational, Scientific and Cultural Organization (UNESCO), seeks to support creating the conditions for fomenting "values, attitudes, modes of behaviour, and ways of life that reject violence and prevent conflicts by tackling their root causes to solve problems through dialogue and negotiation among individuals, groups and nations" (UN General Assembly 1998). ${ }^{6}$ In this conceptualisation of peace education as educating towards building cultures of peace, UNESCO broadly defines culture as "the practices, representations, expressions, knowledge, skills-as well as the instruments, objects, artefacts and cultural spaces associated therewiththat communities, groups and, in some cases, individuals recognise as part of their cultural heritage" (UNESCO 2003). ${ }^{7}$ According to Christoph

${ }^{6}$ Raised at the international level for the first time at the International Congress on Peace in the Minds of Men in Cote d'Ivoire in July 1989, the culture of peace concept was inspired by a 1986 educational initiative of Peru called "Cultura de Paz." The Sevilla Manifesto of 1986, in which scientists from around the world stated that war and violence have no biological origin and are not to be seen as an essential part of human nature but are social inventions, also served as a catalyst for the launch of UNESCO's Culture of Peace Programme in 1994 (Labrador 2003; Lum 2013). The culture of peace initiative reverberates to this day in the Sustainable Development Goals. Target 4.7 explicitly includes the "promotion of a culture of peace and non-violence" under the heading Education for Sustainable Development and Global Citizenship (UN General Assembly 2015).

7 In a similar vein, Boulding defines peace culture as a "mosaic of identities, attitudes, values, beliefs, and patterns of behaviour that lead people to live nurturantly with one 
Wulf, "education for peace plays a central role in the development of a culture of peace" (Wulf 2018: 8). Vice versa, peace education can only develop its full potential when it is embedded in a culture of peace, and not a "culture of violence and war" (Wulf 2018: 7), since it is in the former that "social structures change, and people's actions are oriented towards the values of peace" (Wulf 2018: 6).

Peace education, which "can contribute to the preservation of peace, [but] [...] is not able to secure it" (Wulf 2018: 6), is thus perceived as an intervening variable that can support the building of cultures of peace. To be effective, however, authors like Wulf acknowledge that culturally oriented peace education also has to "deal with the conditions of war, violence and material need, and look for ways of helping to reduce them. [... It does not forget that war and violence are often macro-structurally caused systemic problems, the reduction of which is only partly possible with the help of education. [...] Education for peace must continue to draw back on key concepts such as 'organised peacelessness,' 'structural violence' and 'social justice'" (Wulf 2018: 9) —and human rights and inclusive development, one should add. Yet this last point is not strongly reflected in UNESCO-promoted culture of peace discourse and programmes. The focus of such programmes, which are often based on universalising and homogenising conceptions of peace and culture, has been on shaping distinct sets of values, attitudes, beliefs and modes of behaviour of individuals without offering much by way of addressing the structural causes and drivers of organised violence and war.

\subsection{Critical Approaches to Peace Education}

Contentious and ambivalent as they are, peace education scholarship and praxis have always been subject to critical interrogation regarding their purpose, means and goals. At the risk of oversimplifying what has been a protracted, sometimes torturous and enduring debate within the disperse international peace research and education movement, in its earlier days the issue was one of the new fields having difficulty finding their own identity vis-à-vis the more established social science disciplines, such as sociology, anthropology, economics and political science (Banks 1974; Wiberg 1974). Self-conscious criticism came mostly from within the field

another and the earth itself without the aid of structural power differentials, to deal creatively with their differences and share their resources" (Boulding 2002: 8). 
itself, ${ }^{8}$ while the social science establishment simply shrugged their shoulders: who cares? With the advancement and diversification of the social sciences in general, and of peace research and education in particular, in the past couple of decades this initial phase of soul-searching has gradually given way to a more self-confident stance.

In my view, critical peace scholars and pedagogues, including those from the South, have contributed in no small manner to this development; not least because they have directed the spotlight away from the conventional- "individualistic and morally-appellative" (Zwick 2006: 2)_focus on influencing and shaping attitudes, beliefs, behaviours and values of learners and promoting (universalising and homogenising) cultures of peace (Cremin 2016), to paying more attention to building "new forms and structures of education through curricula, pedagogy, participatory learning, dialogue-based encounters, and multiple perspectives on historical narratives (emphasis added)" (Bajaj and Hantzopoulos 2016: 3; see also Spence and Makuwira 2005). In this vein, the promotion of cultures of peace through education is critiqued for striving to govern "peace through global rationalities of security. These rationalities-embodied in programmes of action, training and capacity-building schemes and information-sharing practices-are geared towards investing in people in ways that individualise them and govern their conduct in the future. Campaigns for 'a culture of peace' attempt to make particular individuals and groups responsible for acquiring certain kinds of values of 'peace' and 'security"' (Ilcan and Phillips 2006: 59). In this critical reading, "security is being redefined as a civil, even scientific issue, and [is] no longer seen as a matter of warheads and delivery systems. It is [thus] not surprising that the principal agent for developing a culture of

8 Among the issues that haunted first-generation peace researchers $\mathrm{cum}$ pedagogues was whether peace education should be on or for peace. In other words, should peace education focus on teaching the insights and results gained from academic peace studies (what could be called the "scientific" approach) or should it strive to educate learners so that they would become peaceful and peace-supporting citizens of the world (what could be called the "normative" and "applied" approach) (see, for instance, Nicklas and Ostermann 1974; Wiberg 1974). In a contribution to the debate published in 1974, Galtung called for "peace education [to] be taken seriously" and "peace research, peace action, and peace education [...] find[ing] each other and integrate into the natural unified whole" (Galtung 1974: 153). Interestingly, and very much in counterflow to conventional academia, his proposal for how to achieve these important goals is based on the idea that the form of peace education ought to guide the development of its contents. 
peace is thought to be the individual and not so much the state" (Ilcan and Philipps 2006: 63).

In contrast, one of the principal goals of critical peace education and scholarship, influenced as they are by Freire's conscientisation approach, is to "empower learners as transformative change agents who critically analyse power dynamics and intersectionalities among race, class, gender, ability-disability, sexual orientation, language, religion, geography and other forms of stratification (emphasis added)" (Bajaj and Hantzopoulos 2016: 4). Here, it is instructive to quote Monisha Bajaj and Maria Hantzopoulos, who offer a crisp characterisation of the differences between critical and conventional peace education.

[...] While all peace educators draw from analyses of violence, critical peace educators pay attention to how unequal social relations and issues of power must inform both peace education and corresponding social action. [...] Critical peace education pays close attention to local realities and local conceptions of peace, amplifying marginalised voices through communitybased research, narratives, oral histories, and locally generated curricula. $[\ldots]$ Other critical approaches [...] also explore the politics and possibilities of enacting peace education in places where contested narratives, identitybased violence, and entrenched structural violence abound. [...] Normative [...] frameworks for understanding peace and peace education must be interrogated and challenged across local and regional contexts (emphasis added). (Bajaj and Hantzopoulos 2016: 4, 7)

Critical peace education, with its outlook on local emancipation and empowerment, is sometimes also framed as "pedagogies of resistance $[\ldots]$ that encompass reciprocity, solidarity and [...] horizontal decision-making structures" (Bajaj 2015: 157). Taking issue with "modern concepts of peace that promote suffocating homogeneity, security, assimilation, false ideals and limited horizons" and are "deeply embedded within warrior ethics, fear and in/security" (Cremin 2016: 3), the critical school perceives peace in an open manner as a desirable context-specific condition of humanity that results from "the abolition of direct or physical violence and structural and cultural violence, [and of] the entrenched inequality and social hierarchies that deprive individuals of their basic human rights" (Bajaj 2015: 156). However, critical discourse concedes that "whether schooling or sites of education themselves can achieve this Herculean task [...] is a constant tension in discussions of peace education and critical peace education" (Bajaj 2015: 156; see also Cremin 2016). 
Furthermore, critical approaches are under pressure to show convincingly how individual empowerment and emancipation could lead to broader collective and institutional transformation-even if such approaches are more cognisant than conventional ones about "the ways in which human agency dynamically interacts with structures and forms of violence" (Bajaj and Hantzopoulos 2016: 4).

While these issues remain to be resolved at the theoretical, empirical and pedagogical levels, they are of little practical import for peace researchers and educators in countries ravaged by all manner of violences, injustices, inequalities and human rights abuses. In other words, in settings characterised by "intractable and belligerent conflict" (Salomon 2002, 2010) and historic "organised peacelessness" (Wulf 2018) where access to education and schooling is limited and highly unequal, promoting peace through education is a task that in any case cannot be accomplished by working (mostly) from within formal institutional structures. Witnessing daily the immediacy of different types of direct, structural and cultural violence and how they affect individuals, families and communities, scholars and pedagogues in countries like Colombia, many of whom are women, would find it difficult not to engage in transformative and empowering peace education discourses and practices, including by leaving the confines of schools and higher education institutes and working with victims' and other social organisations at the local level and in rural communities (Focus Group 2020; see also González 2016; Ortega 2016). Their contributions to the field of peace education tend to be of a critical type. However, I suggest that this is primarily the case not because they have chosen to work within a critical peace education framework but because their immediate violenceinflected socio-political context leaves them no other option. It is for this reason that I believe that both the critical and conventional schools of peace education in the North have much to learn from their peers in the South, while also ensuring that their own work is shared more broadly across the globe. ${ }^{9}$

9 The literature review conducted for this research reveals that meaningful learning and exchange between peace researchers and pedagogues in democratic and prosperous countries, on the one hand, and violence-inflected developing countries on the other remains limited. For instance, Colombian scholars and educators appear to have little access to relevant international debates and discourses, especially to those of Anglo-American and European provenance. This is reflected in the fact that only few international contributions 


\subsubsection{Comparative Features of Conventional and Critical Approaches to Peace Education}

Based on the discussion of conventional and critical approaches to peace education presented in the previous two subsections, which explicitly serves the purpose of broader illustration and is not to be understood as exhaustive, in Table 2.1 below I summarise some key comparative features of the two schools of thought regarding their respective (a) outlook; (b) conceptions of peace, education and pedagogy; (c) underlying theory of change and (d) level of education.

Table 2.1 Comparative features of conventional and critical approaches to peace education

\begin{tabular}{|c|c|c|}
\hline Analytical domains & Conventional peace education & Critical peace education \\
\hline Outlook & $\begin{array}{l}\text { Normative, individualistic and } \\
\text { morally appellative, apolitical, } \\
\text { universalist; geared at influencing } \\
\text { and shaping attitudes, beliefs, } \\
\text { behaviours and values of young } \\
\text { individuals to become "good," } \\
\text { non-violent citizens of the world; } \\
\text { peace education as indirect solution } \\
\text { to problems of violence }\end{array}$ & $\begin{array}{l}\text { Emancipatory, political and } \\
\text { radical; geared at } \\
\text { empowering people as well } \\
\text { as collectives to become } \\
\text { agents of structural social } \\
\text { transformation, especially } \\
\text { at the local level; peace } \\
\text { education as social action } \\
\text { aimed at finding structural } \\
\text { solutions to violence and } \\
\text { inequality }\end{array}$ \\
\hline Peace & $\begin{array}{l}\text { Absence of diverse forms and } \\
\text { processes of context-specific physical } \\
\text { and other violence; presence of } \\
\text { universally accepted attitudes, beliefs, } \\
\text { behaviours and values that enable } \\
\text { individuals and collectives to live in } \\
\text { harmony }\end{array}$ & $\begin{array}{l}\text { Presence of social equity } \\
\text { and justice and empathy; } \\
\text { absence of all forms of } \\
\text { physical, psychological, } \\
\text { structural and cultural } \\
\text { forms of violence and of a } \\
\text { system of peacelessness; } \\
\text { absence of unequal social } \\
\text { relations; absence of power } \\
\text { relationships that deprive } \\
\text { people of their human } \\
\text { rights }\end{array}$ \\
\hline
\end{tabular}

(continued)

to the field are being discussed in the Colombian literature. This book seeks to contribute to bridging some of the gaps between these distanced academic and pedagogical worlds. 
Table 2.1 (continued)

\begin{tabular}{|c|c|c|}
\hline Analytical domains & Conventional peace education & Critical peace education \\
\hline Education & $\begin{array}{l}\text { Process of shaping individual } \\
\text { learners' attitudes, beliefs, behaviours } \\
\text { and values to promote non-violent } \\
\text { coexistence }\end{array}$ & $\begin{array}{l}\text { Process of empowering } \\
\text { people and collectives to } \\
\text { acquire competences and } \\
\text { skills to bring about social } \\
\text { transformation }\end{array}$ \\
\hline Pedagogy & $\begin{array}{l}\text { Teachers influence and shape } \\
\text { learners' attitudes, beliefs, behaviours } \\
\text { and values; value-oriented teaching } \\
\text { and learning; focussed more on the } \\
\text { "what" than the "how" of teaching }\end{array}$ & $\begin{array}{l}\text { Teachers and learners } \\
\text { cooperate in participatory, } \\
\text { dialogue-based, } \\
\text { open-ended, critical, } \\
\text { inclusionary, experiential } \\
\text { and problem-based } \\
\text { learning; focussed on the } \\
\text { "how" and the "what" of } \\
\text { learning and teaching }\end{array}$ \\
\hline Theory of change & $\begin{array}{l}\text { Promoting peace through massive } \\
\text { individual socialisation in formal } \\
\text { educational establishments, and } \\
\text { individual-collective reconciliation in } \\
\text { cultures of peace }\end{array}$ & $\begin{array}{l}\text { Promoting peace through } \\
\text { localised, bottom-up } \\
\text { empowerment of people in } \\
\text { formal and informal } \\
\text { educational establishments, } \\
\text { and direct transformative } \\
\text { social action in wider } \\
\text { society }\end{array}$ \\
\hline $\begin{array}{l}\text { Level of } \\
\text { education }\end{array}$ & $\begin{array}{l}\text { Mostly primary and secondary } \\
\text { school; undergraduate university } \\
\text { courses }\end{array}$ & $\begin{array}{l}\text { Mostly secondary school } \\
\text { and undergraduate and } \\
\text { graduate university } \\
\text { courses; adult learning }\end{array}$ \\
\hline
\end{tabular}

Source Own elaboration based on the literature discussed and cited in this book

\subsection{Peace Education in Colombia: Context and Challenges}

Not a new field of scholarly enquiry and pedagogical praxis, in recent years work on peace education at Colombian schools and higher education institutes has gained momentum. This development has been promoted by the peace process between the Santos administration and FARC, which officially unfolded in Cuba in the period 2012-2016 and resulted in the signing of a final peace accord in November 2016.

10 Given that peace education scholars and pedagogues often do not specify to which level of education they are referring, my characterisation of this particular feature of the conventional and critical approaches to peace education is tentative. 
While the agreement in itself contains only scant references to education, Colombian academia, the educational sector and civil society have seized upon the opportunity afforded by the peace process and several pieces of associated legislation, particularly Law 1448 (2011) on victims and Law 1732 (2014) on the Cátedra de la Paz (Peace Chair), to energise peace education. This is evidenced by a flurry of academic and civil society activities in relation to peace education that the country has witnessed in the past few years, such as a string of forums and conferences at higher and vocational education institutes, and the creation and/or further development of several university centres and specialised study programmes on peace education and peacebuilding. ${ }^{11}$ On the part of the government, attention to peace education in schools and higher education institutes is reflected in several pieces of legislation, foremost Law 1448 of $2011^{12}$ and Law 1732 of $2014 .^{13}$

11 Among such conferences and forums were the National Meeting on Peace Education (Encuentro Nacional de Educación para la Paz) in October 2015; the First International Congress on Education and Society: the role of education in peacebuilding (Primer Congreso Internacional de Educación y Sociedad: el papel de la educación en la construcción de la paz) at Universidad de La Salle in November 2016; the annual conferences of REDUNIPAZ, a university alliance on peace education dating back to the late 1990s; and a series of public debates organised by Colombia's National Vocational Training Service (SENA in Spanish), in one of which the author of this study participated in Cali in 2017. At the level of the Andean region, the UNESCO Chair on Culture and Education for Peace at Universidad Técnica Particular de Loja in neighbouring Ecuador began establishing collaborations with higher education institutes in Colombia, such as the Centro de Investigación y Estudios en Paz, Conflictos y Desarrollo (CIPAZ) at Universidad de Pamplona (Santander department). Recently created study programmes and higher education centres that focus on peace education or include an emphasis on peacebuilding are the Centro de Estudios en Educación para la Paz at Universidad de La Sabana, the UNESCO Chair on Education and a Culture of Peace at Universidad del Rosario, and the MA in Peacebuilding at Universidad de Los Andes, among others. Entrusted with coordinating the MA in Government at Universidad Icesi in Cali in the period 2016-2018, the author of this book developed the extant curriculum to include a focus on the challenges and governance of peacebuilding in Colombia.

12 Law 1448, popularly known as "victims' law," is a key piece of legislation proposed by, and adopted during, the Santos administration. Focused on legally recognising the victims of the armed conflict, safeguarding their fundamental rights and providing guarantees for the non-repetition of human rights abuses and atrocious crimes, the law stipulates the creation of a "social pedagogy that promotes the constitutional values that form the basis for reconciliation" and the "design and implementation of pedagogical strategies that empower victims legally (author's translation)" (Gobierno de Colombia 2011: art. 149).

13 Some Colombian authors also include Law 975 of 2005, the so-called "justice and peace law," in the list of pieces of legislation promoting peace education in contem- 
Seeking to institutionalise peace education as part of its broader peace effort, in 2014-2015 the Santos administration instituted the Peace Chair through Law 1732 of 2014 and Regulatory Decree 1083 of 2015. The new legislation, which was elaborated centrally and did not result from broader consultations by the national government with Colombia's wider education sector (Grajales 2018), ${ }^{14}$ stipulates that all educational entities in Colombia-from primary school through to university-must establish and operate a Cátedra de la Paz by 31 December 2015 (Gobierno de Colombia 2014, 2015). The Peace Chair's stated overarching goal is to "encourage the process of appropriation of knowledge and skills related to territory, culture, economic and social context and historical memory, with the aim of reconstructing the social fabric, promoting prosperity and ensuring the effectiveness of the principles, rights and duties enshrined in the Constitution (author's translation)" (Gobierno de Colombia 2015: art. 2). This is to be achieved through learning, reflection and dialogue on: (a) a culture of peace; (b) peace education and (c) sustainable development.

In keeping with what is an extraordinarily broad underlying conception of peace education, the regulatory decree lists 12 thematic areas that are to constitute the core contents of the Peace Chair: "(a) justice and human rights; (b) the sustainable use of natural resources; (c) protection of the nation's cultural and natural wealth; (d) peaceful conflict resolution; (e) prevention of harassment in schools; (f) diversity and plurality; (g) political participation; (h) historical memory; (i) moral dilemmas; (j) social impact projects; $(\mathrm{k})$ the history of national and international peace accords; (l) life projects and risk prevention (author's translation)" (Gobierno de Colombia 2015: art. 4).

While schools are required to incorporate at least two of the listed thematic areas into their curricula, they can choose which ones at their

porary Colombia (Herrera and Pertuz 2016; Rodríguez 2016). Highly controversial at the time it entered into effect as well as thereafter, Law 975 stipulates that demobilised members of illegal armed groups are entitled to training and education to facilitate their reincorporation into civilian life (Gobierno de Colombia 2005: art. 66).

${ }^{14}$ It is also noteworthy that the legislation gave educational establishments precious little time to introduce peace education into curricula. Issued on 25 May 2015, the regulatory decree stipulates that all pre-school, primary and secondary school programmes are to implement the Peace Chair before 31 December 2015, that is, a mere six months after the legislation's issuance! 
own discretion. Furthermore, the legislation does not provide any guidance on whether peace education should be offered as a subject in its own right or whether any two of the 12 broad topics could simply be grafted onto already existing curricula, such as in ethics and democratic citizenship education (Grajales 2018). With respect to higher education, the scope of indeterminacy and flexibility is even bigger. Referring to article 69 of the country's constitution, which stipulates the autonomy and self-determination of higher education institutes, the national government resolved to leave it up to them to decide what they deem opportune and necessary to offer students by way of peace education.

Of course, it is a truism that one cannot expect any piece of legislation-however well-crafted-to result by virtue of its own existence in positive institutional and social change. Furthermore, it should be stressed that Colombian pedagogues and students have seized in creative fashion upon the opportunity presented by the peace process and the Cátedra de la Paz to further develop existing local discourses on, and practices of, peace education (Focus Group 2020). ${ }^{15}$ This sense of a new beginning is well captured in the words of Ignacio Mantilla, who between 2012 and 2018 served as the rector of the National University of Colombia:

Our post-conflict university must set an example and its role will be to build a new culture, grounded in respect and ethics; a culture of peace and progress based on [...] equality and social inclusion. [This new culture] should replace political intimidation with participation, $[\ldots]$ the pamphlet and the harangue with constructive reflection; it should liberate scientific capacity; and, definitively, it should prevent the vices of politicking from penetrating and becoming entrenched in the university (author's translation). (Mantilla 2016)

This notwithstanding, I believe that overall the Santos administration and lawmakers did the country a small favour with this particular legislation. Ostensibly seeking to pay heed to the SDGs and UNESCO's cultures of peace approach, the terms in which the Cátedra de la Paz is framed come across as arbitrary and too broad for the Peace Chair to galvanise the promotion of peace through education (Focus Group

15 Recent contributions to the literature on peace education in Colombia include Corredor et al. (2018), Diazgranados et al. (2014), Echavarría and Cremin (2019), González (2016), Grajales (2018), Ortega (2016), Salamanca et al. (2016), Vargas et al. (2018), and Villalobos (2018). 
2020; Grajales 2018; Ortega 2016). Although thus far no systematic evaluations of current Colombian peace education are available, first indications are that the field is facing significant challenges (Acevedo and Baéz 2018; Focus Group 2020; Gómez-Suarez 2017; Rodríguez 2016; Semana 2019). I suggest that in part this is due to the conceptual fuzziness of Law 1732 and its failure to prioritise certain key contents, such as education on and for the recovery and preservation of historical memory, over more nebulous ones like "moral dilemmas" or the "protection of the nation's cultural and natural wealth."

Determined not to allow the Cátedra de la Paz to suffer the same fate as past government initiatives on peace education, which tended to obliterate the long-term structural causes of peacelessness and prioritise a focus on civic and ethical issues (Rodríguez 2016), Colombian peace scholars, pedagogues and students are presently engaged in providing the Peace Chair with deeper and more concrete meaning. This includes orienting the field towards critical reflection and a focus on how it could galvanise broader social action beyond the confines of the classroom (Focus Group 2020). Interestingly, this work-in-progress, which is more in line with critical approaches to peace education, is often associated with the recovery and preservation of historical memory among learners and survivors of the armed conflict (Corredor et al. 2018; Focus Group 2020; Girón 2016; Herrera and Pertuz 2016; Merchán 2016; Ortega 2016; Torres 2016). Leading on from my discussion of the (dis)contents of historical memory, which I offer in the following chapter, I present an argument about the challenges but also the relevance and usefulness of historical memory-oriented peace education in countries wrestling with, and emerging from violent conflict, in Chapter 4.

\section{REFERENCES}

Acevedo, Aurymayerly, and Adriana Báez. "La educación en cultura de paz. Herramienta de construcción de paz en el postconflicto." Reflexión Política 20, no. 40 (2018).

Arias, Rosa. "Elementos para pensar una educación para la paz integral." In Bitácora para la cátedra de la paz. Formación de maestros y educadores para una Colombia en paz, edited by Piedad Ortega, 243-262. Bogotá: Universidad Pedagógica Nacional, 2016.

Bajaj, Monisha. "'Pedagogies of resistance' and critical peace education praxis." Journal of Peace Education 12, no. 2 (2015): 154-166. 
Bajaj, Monisha, and Maria Hantzopoulos. "Introduction: Theory, research, and praxis of peace education." In Peace Education. International Perspectives, edited by Monisha Bajaj and Maria Hantzopoulos, 1-16. London: Bloomsbury, 2016.

Banks, Michael. "A critical appraisal of research and teaching on problems of peace and conflict resolution." In Handbook on Peace Education, edited by Christoph Wulf, 35-42. Frankfurt am Main and Oslo: International Peace Research Association, Education Committee, 1974.

Bar-Tal, Daniel. "The elusive nature of peace education." In Peace Education. The Concept, Principles, and Practices Around the World, edited by Gavriel Salomon and Baruch Nevo, 27-36. New York and London: Psychology Press, 2002.

Bar-Tal, Daniel, Ygal Rosen, and Rafi Nets-Zehngut. "Peace education in societies involved in intractable conflicts." In Handbook on Peace Education, edited by Gavriel Salomon and Ed Cairns, 21-43. New York and Hove: Psychology Press, 2010.

Boulding, Elise. "The child and non-violent social change." In Handbook on Peace Education, edited by Christoph Wulf, 101-132. Frankfurt am Main: International Peace Research Association, Education Committee, 1974.

Boulding, Elise. "Peace culture." In Toward a Compassionate Society, edited by M. Afkhami, 8-15. Bethesda, MD: Women’s Learning Partnership, 2002.

Coleman, Peter. "Crises and opportunities: Six contemporary challenges for increasing probabilities for sustainable peace." International Journal of Conflict Engagement and Resolution 1, no. 1 (2013): 96-113.

Corredor, Javier, María Emma Wills, and Mikel Asensio-Brouard. "Historical memory education for peace and justice: Definition of a field." Journal of Peace Education 15, no. 2 (2018): 169-190.

Cremin, Hilary. "Peace education research in the twenty-first century: Three concepts facing crisis or opportunity?" Journal of Peace Education 13, no. 1 (2016): 1-17.

Danesh, H. "The education for peace integrative curriculum: Concepts, contents and efficacy." Journal of Peace Education 5, no. 2 (2008): 157-173.

Diazgranados, Silvia, James Noonan, Steven Brion-Meisels, Lina Saldarriaga, and Berta Daza, Minerva Chávez, and Irena Antonellis. “Transformative peace education with teachers: Lessons from Juegos de Paz in rural Colombia." Journal of Peace Education 11, no. 2 (2014): 150-161.

Echevarría, Josefina, and Hilary Cremin. "Education for territorial peace in Colombia: What role for transrational peace?" Journal of Peace Education 16, no. 3 (2019): 316-338.

Focus Group. "Written comments by members of a group of former students (3) and academic peers (2) at Universidad Icesi on previous versions of this study." Transcript. Universidad Icesi, 2020. 
Freire, Paolo. Pedagogy of the Oppressed. 30th anniversary edition. New York: Bloomsbury, 1968/2000.

Frieters-Reermann, Norbert. Frieden lernen. Friedens- und Konfliktpädagogik aus systemisch-konstruktivistischer Perspektive. Duisburg and Köln: WikuWissenschaftverlag Dr. Stein, 2009.

Frieters-Reermann, Norbert. "Herausforderungen der gegenwärtigen Friedensbildung und Friedenspädagogik." Zeitschrift für internationale Bildungsforschung und Entwicklungspädagogik 33, no. 4 (2010): 4-12.

Galtung, Johan. "Violence, peace and peace research." Journal of Peace Research 6, no 3 (1969): 167-191.

Galtung, Johan. "On peace education." In Handbook on Peace Education, edited by Christoph Wulf, 153-172. Frankfurt am Main: International Peace Research Association, Education Committee, 1974.

Galtung, Johan. A Theory of Peace: Building Direct Structural Cultural Peace. Oslo: Kolofon Press, 2012.

Galtung, Johan. "Peace: A peace practitioner's guide." Ideas for Peace 13 (2017): $1-16$.

Girón, Claudia. "La dimension psicosocial de la educación para la paz." In Bitácora para la cátedra de la paz. Formación de maestros y educadores para una Colombia en paz, edited by Pilar Ortega, 159-185. Bogotá: Universidad Pedagógica Nacional, 2016.

Gobierno de Colombia. "Decreto 1038 de 2015 (mayo 25)." Diario Oficial (2015). Accessed 29 May 2020: http://www.suin-juriscol.gov.co/viewDo cument.asp?ruta=Decretos $/ 30019815$

Gobierno de Colombia. "Ley 1732 de 2014 (septiembre 01)." Diario Oficial (2014). Accessed 4 June 2020: http://www.suin-juriscol.gov.co/viewDocum ent.asp?ruta $=$ Leyes $/ 1687408$

Gobierno de Colombia. "Ley 1448 de 2011 (junio 10)." Diario Oficial (2011). Accessed 10 June 2020: http://wp.presidencia.gov.co/sitios/normat iva/leyes/Documents/Juridica/LEY\%201448\%20DE\%202011.pdf

Gobierno de Colombia. "Ley 975 de 2005 (julio 25)." Diario Oficial (2005). Accessed 10 June 2020: http://www.secretariasenado.gov.co/senado/bas edoc/ley_0975_2005.html

Gómez-Suarez, Andrei. "Peace process pedagogy: Lessons from the no-vote in the Colombian peace referendum." Comparative Education 53, no. 3 (2017): $462-482$.

González, Luisa. ed. Pensar en educación para la paz. Apuestas del Encuentro Nacional de Educación para la paz. Bogotá: Pictograma Creativos SAS, 2016.

Grajales, Nathalie. "Construcción de paz y pedagogía: pensando los contenidos de la cátedra de la paz para Colombia." Revista Ciudad Paz-ando 11, no. 1 (2018): 1-16. 
Gur-Ze'ev, Ilan. "Philosophy of peace education in a postmetaphysical era." In Handbook on Peace Education, edited by Gavriel Salomon and Ed Cairns, 171-183. New York: Psychology Press, 2010.

Harber, Clive. Schooling as Violence. How Schools Harm Pupils and Societies. Abingdon: Routledge Falmer, 2004.

Harris, Ian. "Conceptual underpinnings of peace education." In Peace Education. The Concept, Principles, and Practices Around the World, edited by Gavriel Salomon and Baruch Nevo, 15-26. New York: Psychology Press, 2002.

Harris, Ian. "Peace education theory." Journal of Peace Education 1, no. 1 (2004): 5-20.

Harris, Ian, and Mary Morrison. Peace Education. Third edition. Jefferson: McFarland \& Company, Inc., 2013.

Harris, Simon, and Nick Lewer. "Post-graduate peace education in Sri Lanka." Journal of Peace Education 2, no. 2 (2005): 109-124.

Herrera, Martha, and Carol Pertuz. "Cuento para no olvidar." In Bitácora para la cátedra de la paz. Formación de maestros y educadores para una Colombia en paz, edited by Pilar Ortega, 187-218. Bogotá: Universidad Pedagógica Nacional, 2016.

Hornby, A. S. Oxford Advanced Learner's Dictionary. Sixth edition. Oxford: Oxford University Press, 2000.

Howlett, Charles, and Ian Harris. Books, Not Bombs: Teaching Peace Since the Dawn of the Republic. Charlotte: Information Age Publishing, 2010.

Ilcan, Susan, and Lynne Phillips. "Governing Peace: Global Rationalities of Security and UNESCO's Culture of Peace Campaign." Anthropologica 48, no. 1 (2006): 59-71.

Institute for Economics \& Peace. Global Peace Index 2019: Measuring Peace in a Complex World. Sydney: Institute for Economics \& Peace, 2019.

Jackson, Liz. "Globalization and education." In Oxford Research Encyclopaedia, Education. Oxford: Oxford University Press, 2020. https://doi.org/10. 1093 /acrefore/9780190264093.013.52.

Jaeger, Uli. "Friedenspädagogik: Grundlagen, Herausforderungen und Chancen einer Erziehung zum Frieden." In Friedens- und Konfliktforschung. Eine Einfübrung, edited by Peter Imbusch and Ralf Zoll, 537-557. Fourth edition. Wiesbaden: VS Verlag für Sozialwissenschaften, 2006.

Jaeger, Uli. Peace Education and Conflict Transformation. Berlin: Berghof Foundation, 2014.

Labrador, Carmen. "La cultura de paz, marco para la ciudadanía." Revista de Educación, special issue (2003): 155-168.

Lederach, John Paul. The Moral Imagination. The Art and Soul of Building Peace. Oxford: Oxford University Press, 2005.

Lum, Jeannie. "Peace education: Past, present, and future." Journal of Peace Education 10, no. 3 (2013): 219-229. 
Mantilla, Ignacio. "Firmemos la Carta Magna de universidades colombianas." El Espectador, 5 February 2016. Accessed 7 October 2021: https://www.elespe ctador.com/opinion/columnistas/ignacio-mantilla/firmemos-la-carta-magnade-universidades-colombianas-column-615036/.

Merchán, Jeritza. "La pedagogía en la Ley de Víctimas y en los posacuerdos de paz." In Bitácora para la cátedra de la paz. Formación de maestros y educadores para una Colombia en paz, edited by Pilar Ortega, 115-134. Bogotá: Universidad Pedagógica Nacional, 2016.

Mushakoji, Kinhide. "Peace research and education in a global perspective." In Handbook on Peace Education, edited by Christoph Wulf, 3-18. Frankfurt am Main: International Peace Research Association, Education Committee, 1974.

Nicklas, Hans, and Änne Ostermann. "Reflections on a curriculum of peace education." In Handbook on Peace Education, edited by Christoph Wulf, 173184. Frankfurt am Main and Oslo: International Peace Research Association, Education Committee, 1974.

Ortega, Pilar. "La Cátedra de la Paz: Una propuesta de formación." In Bitácora para la cátedra de la paz. Formación de maestros y educadores para una Colombia en paz, edited by Pilar Ortega, 221-242. Bogotá: Universidad Pedagógica Nacional, 2016.

Rodríguez, Sandra. "Lecciones históricas para pensar una cátedra de la paz." In Bitácora para la cátedra de la paz. Formación de maestros y educadores para una Colombia en paz, edited by Pilar Ortega, 135-157. Bogotá: Universidad Pedagógica Nacional, 2016.

Ross, M. "Peace education and political science." In Handbook on Peace Education, edited by Gavriel Salomon and Ed Cairns, 121-134. New York and London: Psychology Press, 2010.

Salamanca, Manuel, Mery Rodríguez, Juan Cruz, Ramiro Ovalle, Miguel Pulido, and Adriana Molano. Guía para la implementación de la Cádedra de la Paz. Bogotá: Editorial Santillana SAS/Pontificia Universidad Javeriana Bogotá, 2016.

Salas, Angela, Gloria Gallo, and Adela Higuera. "La formación ética en la administración y la gestión pública: experiencias de enseñanza en la educación superior colombiana." Integritas. Revista de Ética 2, no. 3 (2019): 82-97.

Salomon, Gavriel. "The nature of peace education: Not all programs are created equal." In Peace Education. The Concept, Principles, and Practices Around the World, edited by G. Salomon and B. Nevo, 3-14. New York: Psychology Press, 2002.

Salomon, Gavriel. "Peace education. Setting the scene." In Handbook on Peace Education, edited by Gavriel Salomon and Ed Cairns, 1-7. New York: Psychology Press, 2010. 
Semana. "Esto es lo que enseñan en la normal Montes de María." 3 September 2019. Accessed 5 June 2020: https://www.semana.com/Item/ArticleAsync/ 604758 ? nextId $=604552$ \&nextId $=602153$

Spence, Rebecca, and Jonathan Makuwira. "Do we make a difference? Teaching and researching peace at tertiary level." Journal of Peace Education 2, no. 1 (2005): 17-31.

Tierney, William. "The role of tertiary education in fixing failed states: Globalization and public goods." Journal of Peace Education 8, no. 2 (2011): 127-142.

Torres, Ingrid. "Pedagogías de la memoria y la enseñanza de la historia para la construcción de una conciencia histórica." In Bitácora para la cátedra de la paz. Formación de maestros y educadores para una Colombia en paz, edited by Pilar Ortega, 263-282. Bogotá: Universidad Pedagógica Nacional, 2016.

UNESCO. Convention for the Safeguarding of the Intangible Cultural Heritage. Paris: UNESCO, 2003. Accessed 10 June 2020: https://ich.unesco.org/en/ convention

UN General Assembly. Resolution A/RES/52/13 on Culture of Peace, 15 January 1998. Accessed 10 June 2020: https://undocs.org/A/RES/52/13

Vargas, Nelly, Andrea Vargas, and Sandra Fragua. "Paz y convivencia escolar: Una experiancia en Ciudad Bolívar." Revista Inclusión y Desarrollo 6, no. 1 (2018): 3-15.

Villalobos, Yeraldo. "Los instrumentos de la Cátedra de Paz, como estrategia en la reconstrucción social de una nueva Colombia." Revista ED 5, no. 1 (2018): 19-35.

Walt, Stephen. "The case against peace." Foreign Policy, 17 June 2016. Accessed 10 June 2020: https://foreignpolicy.com/2016/06/17/the-caseagainst-peace-syria-europe-brexit-donald-trump/.

Webel, Charles. "Toward a philosophy and metapsychology of peace." In Handbook of Peace and Conflict Studies, edited by Charles Webel and Johan Galtung, 3-13. London and New York: Routledge, 2007.

Wiberg, Håkan. "Peace research and peace education: A pessimistic note." In Handbook on Peace Education, edited by Christoph Wulf, 137-149. Frankfurt am Main and Oslo: International Peace Research Association, Education Committee, 1974.

Wulf, Christoph. "Culture of peace and education for peace." In Culture of Peace. A Contribution to UNESCO's Educational Mission: Building Peace in the Minds of Men and Women, 6-14. Berlin: UNESCO Club Berlin/UNESCO Associated Schools in Germany, 2018.

Zwick, Elisabeth. "Pax iusta: Überlegungen zu Grundlagen und Wegen einer Friedenspädagogik.” Bildungsforschung 3, no. 1 (2006). Accessed 10 June 2020: https://www.pedocs.de/volltexte/2014/4646/pdf/bf_2006_1_ Zwick_Pax_Iusta.pdf. 
Open Access This chapter is licensed under the terms of the Creative Commons Attribution 4.0 International License (http://creativecommons.org/licenses/ by $/ 4.0 /$ ), which permits use, sharing, adaptation, distribution and reproduction in any medium or format, as long as you give appropriate credit to the original author(s) and the source, provide a link to the Creative Commons license and indicate if changes were made.

The images or other third party material in this chapter are included in the chapter's Creative Commons license, unless indicated otherwise in a credit line to the material. If material is not included in the chapter's Creative Commons license and your intended use is not permitted by statutory regulation or exceeds the permitted use, you will need to obtain permission directly from the copyright holder.

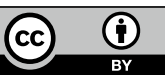

